\title{
Soil microbial community assembly precedes vegetation development after drastic techniques to mitigate effects of nitrogen deposition
}

\author{
A.U. van der Bij ${ }^{1 *}$, M. Pawlett ${ }^{2}$, J.A. Harris ${ }^{2}$, K. Ritz ${ }^{2,3}$ and R. van Diggelen ${ }^{1}$ \\ 1. Ecosystem Management Research Group, University of Antwerp, Universiteitsplein 1, 2610 \\ Wilrijk, Belgium \\ 2. School of Energy, Environment and Agrifood, Cranfield University, Bedfordshire, MK43 OAL, UK \\ 3. Division of Agricultural and Environmental Sciences, School of Biosciences, University of \\ Nottingham, Sutton Bonington, Leicestershire, LE12 5RD, UK \\ * Corresponding author, 0032 32652268, arrie.vanderbij@uantwerpen.be
}

\begin{abstract}
Oligotrophic semi-natural systems are threatened by high levels of nitrogen deposition. To mitigate these effects, drastic techniques such as sod-cutting and topsoil removal are applied to reduce nitrogen loads in existing systems and expand their area on former agricultural fields. We assessed the effects of these techniques along with the influence of previous land-use, isolation and vegetation development on subsequent microbial community assembly in restored agricultural areas. Microbial community phenotypic structure was measured using PLFA-analysis, along with soil chemistry and vegetation development. Differences in soil nitrogen pools due to restoration techniques were the most differentiating factor for both microbial community assembly and vegetation development. Only after topsoil removal was resemblance of both below- and aboveground communities to well-developed heathlands increased within 10-15 years. After sod-cutting both microbial community and vegetation composition remained more similar to agricultural sites. The relative contribution of agricultural sites and heathlands in the direct vicinity had more pronounced effects on local microbial community composition than current land-use in all study sites including agricultural areas and heathlands. Vegetation development was apparently of minor importance for microbial community assembly, since characteristic belowground assembly preceded that of aboveground development in both restoration contexts.
\end{abstract}

Keywords: Heathland; Plant-soil interactions; PLFA; Restoration; Soil chemistry

\section{Introduction}

Soil community assembly is increasingly recognised as an important factor in the restoration of oligotrophic ecosystems (Harris 2009, Kardol \& Wardle 2010, Van der Putten et al. 2013). The presence of specific soil community components such as mycorrhiza might be a pre-requisite for the establishment of characteristic plant species, while microbial community composition is one of the governing factors in relation to nutrient cycling and productivity (Harris 2009). However, despite an assumed strong inter-dependence between above- and below-ground community assembly, the limited number of studies available on restoration chronosequences that include both communities show variable results. Characteristically, either both communities follow the same pattern (Lozano et al. 2014) or soil community assembly lags behind vegetation development (Holtkamp et al. 2008, Jangid et al. 2011). However, to what extent vegetation and soil community assembly depend on each other is still unclear, and remains an active area of research (Harris 2009). 
Nitrogen deposition levels in Western Europe exceed critical values for the persistence of many oligotrophic vegetation types such as heathlands and matgrass swards (Bobbink et al. 2010). With increasing nitrogen availability, eutrophic grasses outcompete oligotrophic forbs, resulting in a loss of characteristic biodiversity (Duprè et al. 2010, Maskell et al. 2010). Efforts to mitigate these effects include both habitat improvement in existing systems and expansion of their size on former agricultural areas. However, semi-natural systems and agricultural sites are situated at opposite ends of a productivity gradient. Agricultural sites contain a productive vegetation and bacteria-dominated microbial community while oligotrophic systems have low-productive vegetation and a fungaldominated microbial community (Wardle et al. 2004, Harris 2009). Sod-cutting and topsoil removal are drastic techniques that are sometimes used to remove excess nitrogen and phosphorus from former agricultural sites, essentially transporting nutrients from the ecosystem compartment (Verhagen et al. 2001). After sod-cutting, where only the topmost layer is stripped, much organic material remains while with topsoil removal the complete organic layer is removed. After the application of such techniques a bare soil without any vegetation and a highly reduced seedbank (Klimkowska et al. 2010) remains. A key factor for the direction of vegetation development are the dispersal abilities of characteristic plant species (Van Diggelen \& Marrs 2003, Cramer et al. 2008). Much less is known about the importance of dispersal in microbial community assembly (Litchman 2010, Nemergut et al. 2013).

Increased nitrogen availability as a consequence of deposition not only changes abiotic conditions in favour of more competitive species, it might also weaken plant-soil interactions (Treseder 2008). In experimental studies high levels of nitrogen addition lead to a decrease in microbial biomass and respiration (Treseder 2008, Liu et al. 2014). Fungal biomass is especially reduced (Treseder 2008, Farrer et al. 2013, Wei et al. 2013), which is likely caused by both a reduced dependence of plants on mycorrhiza and a general decline in saprotrophic fungi (Treseder 2008). Bacterial biomass is generally not affected (Treseder 2008), although some studies show a decrease at high nitrogen levels (Farrer et al. 2013, Wei et al. 2013). Such negative indirect effects of nitrogen deposition are described for existing systems, but it is unknown whether constant high levels of nitrogen deposition also limit the development of characteristic fungal-dominated communities after sod-cutting or topsoil removal.

In this paper we studied whether sod-cutting and topsoil removal were effective techniques for restoring oligotrophic systems on former agricultural sites even under conditions of high nitrogen deposition. We analysed microbial community assembly in recently restored areas in relation to soil nitrogen pool, previous land-use and isolation. We assessed whether high nitrogen levels suppress fungal content and whether a characteristic vegetation development is a precondition for the assembly of an associated and concomitantly characteristic microbial community. We hypothesize 1) that soil nitrogen pool size is the dominant factor controlling microbial community assembly, and 2) that a fungal-dominated microbial community can only develop when the nitrogen pool size is reduced sufficiently.

\section{Materials and methods}

\subsection{Study sites}

We sampled 18 sites in 8 different locations in the northern part of the Netherlands between 2003 and 2009 (Table 1). These sites included former agricultural areas of which 3 were restored by sodcutting (R-SC) and 5 by topsoil removal (R-TR), 4 current agricultural meadows as starting points (Start) and 6 well-developed heathlands with a climax vegetation as target sites (Target). Of the restored areas 3 were former arable fields (F-A) and 5 were former agricultural meadows (F-M). Yearly nitrogen input of (former) agricultural sites was between 150-200 kg N ha-1, meadows were mown several times per year for silage. The degree of isolation was determined by the distance of the site to a large heathland reserve: non-isolated sites were directly adjacent to or part of a reserve, 
low-isolation sites were separated from the reserve by agricultural land but were within $250 \mathrm{~m}$, while there was no reserve in the direct vicinity of the highly-isolated sites. Some of the studied heathlands were highly-isolated, since they were remnants of former larger heathlands that were converted into agriculture. Critical loads of nitrogen deposition for heathlands range from 10-20 kg N ha ${ }^{-1}$ year $^{-1}$ (Bobbink et al. 2010). In 2004 nitrogen deposition levels in the studied sites were between 23.1 and $35 \mathrm{~kg} \mathrm{~N}^{-1}$ year $^{-1}$ (Netherlands Environmental Assessment Agency, www.mnp.nl). In the early 1990s however, when the restoration techniques were applied, nitrogen deposition levels were $30 \%$ higher.

\subsection{Soil chemistry}

Soil chemistry was measured within 2 years after application of the restoration techniques in 19941995 and again in 2001. Since there were only marginal differences between both sampling rounds, the 2001 data were used for analysis. The Dwingeloo sites were sampled simultaneously with the microbial community in 2009. For each sites 10 samples of $0-20 \mathrm{~cm}$ depth were mixed. $\mathrm{pH}(\mathrm{KCl})$ was measured in $15 \mathrm{~g}$ fresh soil after addition of $22.5 \mathrm{ml} 0.11 \mathrm{~mol} / \mathrm{K} \mathrm{KCl}$. Total nitrogen $\left(\mathrm{N}_{\text {tot }}\right)$ was measured on a $\mathrm{C} / \mathrm{N}$-analyzer. Total phosphorus $\left(\mathrm{P}_{\text {tot }}\right)$ was measured with a colorimetric method according to Murphey \& Riley (1962). The measured parameters are compared to values for reference heathlands from De Graaf et al. (2009) and Liczner et al. (2011).

\subsection{Microbial community}

Within each site, a mixed sample of $3 \times 100 \mathrm{~cm}^{3}$ soil cores was obtained with Kopecky rings. Aliquots of the soil were refrigerated for the analysis of microbial biomass or freeze-dried for PLFA-analysis. Except for the Dwingeloo sites, which were sampled in 2009, all sites were sampled in 2003. Microbial biomass- $C$ was determined using the fumigation-extraction procedure (Jenkinson and Powlson 1976) using $\mathrm{K}_{\mathrm{EC}}$ of 0.45 (Vance \& Jenkinson 1987; Joergensen 1996). Microbial phenotypic profiles were determined by phospholipid fatty acid (PLFA) analysis using a method modified from Frostegård et al. (1993) which is further described by Courtney et al. (2014). The mol\% of indicator fatty acids was used as an indicator of the presence of groups of organisms. We determined bacterial

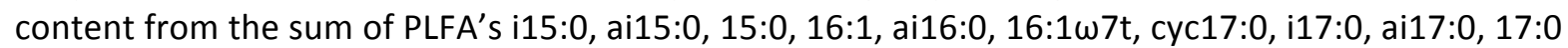
and cyc19:0. PLFA 18:2 $\omega 6,9$ was used for fungal content.

\subsection{Vegetation}

Vegetation relevés $(2 \mathrm{~m} \times 2 \mathrm{~m})$ were made in 2005. The cover of each species was estimated according to the Londo scale (Londo 1976). The presence of characteristic species was calculated with a Saturation Index (SI) according to Klimkowska et al. (2007). Faithfulness values obtained from SynBioSys (Hennekens et al. 2010) were used to determine if species were characteristic, only species with a faithfulness higher than 20 to the dry heath (Calluno-Ulicetea), wet heath (Erica tetralices) or Nardetea plant communities were included. A list of these species is included in Appendix A.

\subsection{Statistical analysis}

We tested the effects of restoration technique, previous land-use and isolation with a linear mixedeffect model (LME) using restricted maximum likelihood (REML) estimation. Restoration technique, previous land-use and isolation were treated as fixed factors, study area as a random effect. We considered our study areas as a collection of random samples from a theoretically large pool to which we would like to extrapolate (Bennington and Thayne 1994). This model allows us to test the main effects of restoration measure, previous land-use and isolation while correcting for variation between sites, in which we were not interested. Normal distribution and equality of variances were tested with a Shapiro-Wilkinson respectively Breuch Pagan test; if needed data were $\ln (x+1)$ 
transformed. The overall effects on microbial community composition were tested with a multivariate LME on the first two factors of a principal component analysis (PCA) of all PLFA's, including study area as random effect. Subsequently the effects of restoration technique, land-use and isolation on microbial community composition were tested with a Linear Discriminant Analysis (LDA) including all PLFA's. Structure matrix correlations were used for interpretation. To detect differences in overall vegetation composition a Detrended Component Analysis (DCA) was used, significant differences between categories on the first two axis were tested with a LME including study area as random effect. Parallel above- and below-ground assembly was assessed by combining the first LDA-axis of both communities. Significant differences between categories on the first two axis of a LDA were tested with an Analysis of Variance (ANOVA) and a post-hoc Tukey test. R 3.2.2 (R Core Team 2016), the nlme-package for LME (Pinheiro et al. 2015) and SPSS 23 (IBM Corp) were used for statistics, Canoco 4.5 for Windows (Ter Braak and Šmilauer 2002) for DCA.

\section{Results}

\subsection{Soil chemistry}

Nitrogen pool sizes were reduced significantly after both restoration techniques (Table 2), with even lower pool sizes after topsoil removal ( $L M E, F_{3,4}: 40.80$, p: 0.0019 , Tukey test, $\left.p<0.05\right)$. Phosphorus pools also seemed lower after topsoil removal, but these differences were not significant (LME, $F_{3,4}$ : 4.99, $\mathrm{p}$ : 0.3154). $\mathrm{pH}$ did not differ significantly between both restoration techniques, but was lower in heathlands compared to agricultural sites (LME, $F_{3,5}: 7.38, p: 0.0277$, Tukey test, $\left.p<0.05\right)$.

\subsection{Microbial biomass}

Microbial biomass was significantly reduced by both techniques compared to agricultural sites and heathlands ( $L M E, F_{3,67}: 41.81$, $p<0.0001$, Figure 1 ), with significantly lower biomass after topsoil removal than after sod-cutting (Tukey test, $p<0.05$ ). Previous land-use did not affect microbial biomass reduction by both restoration techniques: microbial biomass was equally reduced in former meadows and former arable fields compared to agricultural sites and heathlands ( $L M E, F_{3,67}: 19.20$, $\mathrm{p}<0.0001$, Tukey test, $\mathrm{p}<0.05$ ). Low-isolated sites contained significantly lower microbial biomass compared to highly-isolated sites, non-isolated sites did not differ significantly from both other categories (LME, $F_{2,68}: 8.32$, p: 0.0006, Tukey test, $p<0.05$ ).

\subsection{Microbial community composition}

Restoration technique (LME, $F_{3,73}: 62.32, p<0.0001$ ) and isolation (LME, $F_{2,74}: 12.17, p<0.0001$ ) affected microbial community composition significantly when all measured PLFA's were combined. Although the analysis of previous land-use showed distinct differences between agricultural sites, restored areas and heathlands $\left(L M E, F_{3,73}: 49.56, p<0.0001\right)$, there were no significant differences between former arable fields and former meadows (Tukey test, $p>0.05$ ).

The sites after both restoration techniques ordinated between the agricultural sites and heathlands on the first linear discriminant (Figure 2), with significant differences between all categories (statistics in Appendix B). Microbial community composition after sod-cutting showed a greater resemblance to agricultural sites, and after topsoil removal it ordinated closer to the heathlands. The fungal PLFA $(18: 2 \omega 6,9)$ was positively correlated with the first discriminant, while several bacterial

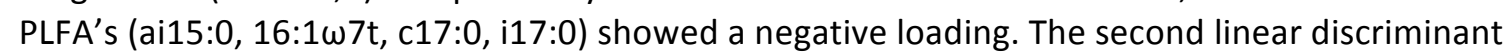
separated the restored sites from older soils. Microbial community composition in all degrees of isolation differed significantly from each other on the first discriminant (Tukey test, $p<0.05$ ), with a negative loading of the fungal PLFA $(18: 2 \omega 6,9)$ and a positive loading of several mainly bacterial PLFA's (15:0, i16:0, 18:0 isomer and 19:2). The second linear discriminant separated microbial 
community composition of low-isolated sites from the other two categories (Tukey test, $p<0.05$ ), with a positive loading of the fungal PLFA and a negative loading of several bacterial PLFA's (ai15:0,

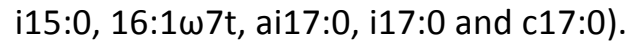

Bacterial and fungal content showed the same pattern as the PLFAs loadings on the first linear discriminant for restoration techniques (Figure 3). The fungal content was significantly higher in heathlands and after topsoil removal compared to the agricultural sites and sod-cutted areas (LME, $F_{3,73}: 28.35, p<0.0001$, Tukey test, $\left.p<0.05\right)$. The lowest bacterial content was found after topsoil removal, although these sites did not differ significantly from heathlands ( $L M E, F_{3,73}: 16.38, p<0.0001$, Tukey test, $p<0.05)$. Bacterial content after sod-cutting was similar to both agricultural sites and heathlands (Tukey test, $p<0.05$ ). Although the analysis of previous land-use showed significant differences between agricultural sites, restored areas and heathlands, there were no significant differences in fungal or bacterial content between former arable fields and former meadows (Tukey test, $p<0.05)$. In highly-isolated areas bacterial content was lower compared to non-isolated sites, while sites with low-isolation did not differ from both other categories (LME, $F_{2,74}: 5.19, p: 0.0078$, Tukey test, $\mathrm{p}<0.05)$. On the contrary, fungal content was significantly higher in highly-isolated sites compared to low- and non-isolated sites (LME, $F_{2,74}: 9.99$, p:0.0001, Tukey test, $p<0.05$ )

\subsection{Vegetation}

Vegetation development showed a generally similar pattern to microbial community assembly, although differences between restoration techniques were less distinct and not significant (Figure 4). The saturation index differed significantly between agricultural sites and heathlands but not between both restoration techniques (LME, $F_{3,7}: 5.19, p: 0.0337$, Tukey test, $p<0.05$ ). Characteristic heathland species were absent in agricultural sites and after sod-cutting, while their presence was highly variable after topsoil removal. Three out of five sites after topsoil removal had a similar number of characteristic species as heathlands, while in the other two sites these species were still absent. The absolute cover of characteristic heathland species showed a similar pattern (LME, $F_{3,7}: 37.83$, $\mathrm{p}: 0.0001$ ), with a significant higher cover of heathland species after topsoil removal compared to sod-cutting, but still significantly lower compared to heathlands (Tukey test, $p<0.05$ ). The absolute cover of agricultural species showed the opposite pattern, although differences between both restoration techniques were not significant $\left(L M E, F_{3,7}: 7.03, p: 0.0161\right.$, Tukey test, $\left.p<0.05\right)$. A DCA of vegetation composition showed a clear separation between agricultural sites and heathlands on the first axis (LME, $F_{3,7}: 21.37, p: 0.0007$, Tukey test, $p<0.05$, Figure 5). Although highly variable, vegetation composition after topsoil removal differed significantly from both agricultural sites and heathlands (Tukey test, $\mathrm{p}<0.05$ ). Vegetation composition after sod-cutting did not differ significantly from agricultural sites.

\subsection{Parallel above-below-ground development}

Both above- and below-ground distinct differences in community composition related to restoration technique were found on the first axis of the multivariate analysis. A combination of the first LDAaxis of vegetation and microbial community composition shows a pattern of increasing resemblance to heathlands (Figure 6). With sod-cutting the resemblance only slightly increased below-ground, while vegetation composition remained in the same domain of the ordination for the agricultural context. After topsoil removal below-ground resemblance to heathlands increased in all sites irrespective of highly variable above-ground development. After both techniques microbial community composition showed a greater resemblance to heathlands than vegetation composition, and seemed to precede vegetation development.

\section{Discussion}




\subsection{Effects of soil nutrient pools}

Differences in nitrogen availability had a pronounced effect on microbial community assembly, especially with respect to fungi. Fungal content was higher at low nitrogen availability and low at higher nitrogen levels, which is similar to the pattern observed in nitrogen addition studies (Treseder 2008, Wei et al. 2013, Liu et al. 2014, Freedman et al. 2015). Bacterial content, however, showed the opposite pattern, with higher content at high nitrogen availability. This resulted in a low fungal/bacterial ratio after sod-cutting and a high fungal/bacterial ratio after topsoil removal, reflecting characteristic differences between fertile and oligotrophic systems (Wardle et al. 2004, Harris 2009). The expected negative effects of high nitrogen deposition levels on fungi (Treseder 2008, Farrer et al. 2013, Wei et al. 2013) did not prevent the development of a fungal-dominated community, apparently soil nitrogen pool size was still the dominant factor for microbial community assembly. Soil nitrogen pools after topsoil removal lie within the range of the target system in comparison to the meta-analysis of De Graaf et al. (2009). After sod-cutting nitrogen availability was much higher than the maximum range for heathlands. Phosphorus pools after both restoration techniques were still larger than the upper bounds for heathland habitats (De Graaf et al. 2009), leading to conditions where oligotrophic systems can only be supported after topsoil removal because of highly reduced nitrogen soil pools. $\mathrm{N}: \mathrm{P}$ ratios in the vegetation after topsoil removal ranged from 3.8 to 8.5 (van Diggelen, unpublished data), which suggests that productivity is limited by nitrogen (Koerselman \& Meuleman 1996). Despite high levels of nitrogen deposition, soil nitrogen pools remained still low in the first decades, maintaining suitable conditions for oligotrophic systems. However, optimal conditions for oligotrophic system development might change after a few decades. Constant high levels of nitrogen deposition may lead to increased nitrogen availability, which in combination with the large phosphorus pools increases productivity and favours a shift towards more eutrophic species (Duprè et al. 2010, Maskell et al. 2010). This shift could be enhanced by indirect effects of high nitrogen deposition levels, such as weakening the interaction between mycorrhiza and host plants (Treseder 2008). The establishment of an interaction between heather (Calluna vulgaris) and ericoid mycorrhiza is considered essential in heathland restoration (Read et al. 2004, Diaz et al. 2008).

\subsection{Impact of cultural legacy and isolation}

Several studies have reported differences in microbial community composition between arable fields and agricultural meadows (Francisco et al. 2016, Griffiths et al. 2016). Interestingly, we found no such differences in microbial community composition between former arable fields and former meadows: none of the most differentiating PLFAs (Francisco et al. 2016) differed significantly between both categories. Similar to reduced soil fauna densities after sod-cutting and topsoil removal (Frouz et al. 2009), most of the original microbial biomass was also removed after application of these techniques. Apparently the cultivation legacy is most prominent in the upper soil layer, and is removed with the application of both restoration techniques.

Characteristic plant species often have difficulties to reach highly-isolated sites, leading to differences in vegetation composition between isolated and well-connected sites (Cramer et al. 2008, Myers \& Harms 2009). Remarkably, isolated microbial communities from highly-isolated sites differed less from heathlands in fungal/bacterial ratio than those in low- or non-isolated sites. Higher initial availability of organic material might promote fungal establishment more than bacteria, as fungi are more dependent on organic material availability (Schmidt et al. 2014). The effects of isolation on microbial community composition were independent from land-use category. This suggests that across radical different systems the relative contribution of agricultural sites and heathlands in the direct vicinity had a more profound effect on local microbial community composition than actual land-use. 


\subsection{Dependence of microbial community assembly on vegetation development}

Studies on simultaneous development of both vegetation and soil communities after land abandonment reported either similar trajectories of faster vegetation development (Jangid et al. 2011, Lozano et al. 2014), while after topsoil removal soil community assembly lags behind vegetation development (Holtkamp et al. 2008, Frouz et al. 2009). Contrary to these studies, we found more pronounced patterns in microbial community assembly after the application of both restoration techniques. Microbial community composition after topsoil removal was more similar to heathlands, while vegetation composition was still highly variable. A similar pattern was found after sod-cutting, where vegetation composition remained very similar to agricultural meadows while microbial community composition already showed more resemblance to reference heathlands. Both techniques minimize above- and below-ground competition with removal of 1) the vegetation, 2) soil seedbank (Török et al. 2008) and 3) most of the soil community. The first phases in vegetation development are determined mainly by dispersal rates of immigrating species and seed pressure from remaining species (Myers \& Harms 2009). Since the seedbank that remains contain mostly ruderal and agricultural species (Klimkowska et al. 2010), seed pressure of the latter species is presumably high in all restored areas. After shallow sod-cutting these common species can gain dominance fast, while they are almost absent after topsoil removal, leaving a 'window of opportunity' for oligotrophic target species to establish. Disturbances such as sod-cutting or topsoil removal increase the probability of dramatic shifts in microbial community composition, assumed to be caused either by selective pressures or neutral processes (Litchman 2010, Nemergut et al. 2013). Contrary to other studies (Holtkamp et al. 2008, Frouz et al. 2009, Jangid et al. 2011, Lozano et al. 2014), microbial community assembly preceded vegetation development in the present situation. The clear effects of both soil nitrogen availability and regional species pool on microbial community assembly suggest that here interactions between the abiotic environment and the local microbial community play a determining role.

\subsection{Implications for mitigating effects of nitrogen deposition}

Our results show that in former agricultural sites only topsoil removal can mitigate the effects of enhanced nitrogen availability sufficiently fast. When nitrogen availability in the soil is reduced, conditions are suitable for the development of characteristic communities both above- and belowground, even under constantly high levels of nitrogen deposition. Vegetation development can be facilitated by enhancing dispersal via hay transfer (Kiehl et al. 2010, Klimkowska et al. 2010), while soil inoculation might enhance below-ground development (Wubs et al. 2016). Unfortunately, in the mid- to long-term the combination of a large phosphorus pool and a high nitrogen deposition likely will shift both above- and below-ground communities backwards towards a degraded state (Duprè et al. 2010, Maskell et al. 2010). With topsoil removal suitable starting conditions can be created, but under conditions of high nitrogen deposition management activities such as sod-cutting remain essential to conserve these systems in the mid to long term.

\section{Acknowledgements}

We are grateful to the managers of Staatsbosbeheer, Vereniging Natuurmonumenten, It Fryske Gea and Het Groninger Landschap for their permission to work at our sites. This study was financed by Het Prins Bernard Fonds, Vereniging Natuurmonumenten and the provinces Groningen, Friesland and Drenthe, the Netherlands.

\section{References}

Bennington, C.C. and Thayne, W.V. 1994. Use and misuse of mixed-model analysis of variance in ecological-studies. Ecology 75, 717-722 
Bobbink, R., Hicks, K., Galloway, J. Spranger, T., Alkemade, R., Ashmore, M., Bustamante, M., Cinderby, S., Davidson, E., Dentener, F., Emmett, B., Erisman, J.-W., Fenn, M., Gilliam, F., Nordin, A., Pardo, L., and De Vries, W. 2010. Global assessment of nitrogen deposition effects on terrestrial plant diversity: a synthesis. Ecol. Appl. 20, 30-59

Courtney, R., Harris, J.A., Pawlett, M. 2014. Microbial community composition in a rehabilitated bauxite residue disposal area: a case study for improving microbial community composition. Restor. Ecol. 22, 798-805

Cramer, V.A., Hobbs, R.J. and Standish, R.J. 2008. What's new about old fields? Land abandonment and ecosystem assembly. Trends Ecol. Evol. 23, 104-112

De Graaf, M.C.C., Bobbink, R., Smits, N.A.C., Van Diggelen, R. and Roelofs, J.G.M. 2009. Biodiversity, vegetation gradients and key biogeochemical processes in the heathland landscape. Biol. Cons. 142, 2191-2201

Diaz, A., Green, I. and Tibbett, M. 2008. Re-creation of heathland on improved pasture using top soil removal and sulphur amendments: edaphic drivers and impacts on ericoid mycorrhizas. Biol. Cons. $141,1628-1635$

Duprè, C.., Stevens, C.J., Ranke, T., Bleeker, A., Peppler-Lisbach, C., Gowing, D.J.G., Dise, N.B., Dorland, E., Bobbink, R. and Diekmann, M. 2010. Changes in species richness and composition in European acidic grasslands over the past 70 years: the contribution of cumulative atmospheric nitrogen deposition. Glob. Chang. Biol. 16, 344-357

Farrer, E.C., Herman, D.J., Franzova, E. and Pham, T. 2013. Nitrogen deposition, plant carbon allocation, and soil microbes: Changing interactions due to enrichment. Am. J. Bot. 100, 1458-1470

Francisco, R., Stone, D., Creamer, R.E., Sousa, J.P. and Morais, P.V. 2016. European scale analysis of phospholipid fatty acid composition of soils to establish operating ranges. Appl. Soil Ecol. 97, 49-60

Freedman, Z.B., Romanowicz, K.J. Upchurch, R.A. and Zak, D.R. 2015. Differential responses of total and active soil microbial communities to long-term experimental $\mathrm{N}$ deposition. Soil Biol. Biochem. 90, 275-282

Frostegård, Å., Tunlind, A. and Bååth, E. 1993. Phospholipid fatty acid composition, Biomass, and activity of microbial communities from two soil types experimentally exposed to different heavy metals. Appl. Environ. Microbiol. 59, 3605-3617

Frouz, J., Van Diggelen, R., Pižl, V., Starý, J., Hánĕl, L., Tajovský, K. and Kalčík, J. 2009. The effect of topsoil removal in restored heathland on soil fauna, topsoil microstructure, and cellulose decomposition: implications for ecosystem restoration. Biodivers. Conserv. 18, 3963-3978

Griffiths, R.I., Thomson, B.C., Plassart, P., Gweon, H.S., Stone, D., Creamer, R.E., Lemanceau, P. and Bailey, M.J. 2016. Mapping and validating predictions of soil bacterial biodiversity using European and national scale datasets. Appl. Soil Ecol. 97, 61-68

Harris, J. 2009. Soil microbial communities and restoration ecology: facilitators or followers? Science $325,573-574$ 
Hennekens, S.M., Smits, N.A.C., and Schaminée, J.H.J. 2010. SynBioSys Nederland versie 2. Alterra, Wageningen UR.

Holtkamp, R., Kardol, P., Van der Wal, A., Dekker, S.C., Van der Putten, W.H. and De Ruiter P.C. 2008. Soil food web structure during ecosystem development after land abandonment. Appl. Soil Ecol. 39, 23-34

Jangid, K., Williams, M.A., Franzluebbers, A.J., Schmidth, T.M., Coleman, D.C. and Whitman, W.B. 2011. Land-use history has a stronger impact on soil microbial community composition than aboveground vegetation and soil properties. Soil Biol. Biochem. 43, 2184-2193

Jenkinson D.S. and Powlson D.S. 1976. The effects of biocidal treatments on metabolism in soil-I. fumigation with chloroform. Soil Biol. Biochem. 8:167-177

Joergensen R.G. 1996. The fumigation-extraction method to estimate soil microbial biomass: Calibration of the kEC value. Soil Biol. Biochem. 28:25-31

Kardol, P. and Wardle, D.A. 2010. How understanding aboveground-belowground linkages can assist restoration ecology. Trends Ecol. Evol. 25, 670-679

Kiehl, K., Kirmer, A., Donath, T.W., Rasran, L. and Hölzel, N. 2010. Species introduction in restoration projects - Evaluation of different techniques for the establishment of semi-natural grasslands in Central and Northwestern Europe. Basic Appl. Ecol. 11, 285-299

Klimkowska, A, Van Diggelen, R., Bakker, J.P. and Grootjans A.P. 2007. Wet meadow restoration in Western Europe: A quantitative assessment of the effectiveness of several techniques. Biol. Cons. $140,318-328$

Klimkowska, A., Kotowski, W., Van Diggelen, R., Grootjans, A.P., Dzierża, P. and Brzezińska, K. 2010. Vegetation re-development after fen meadow restoration by topsoil removal and hay transfer. Restor. Ecol. 18, 924-933

Koerselman, W. and Meuleman, A.F.M. 1996. The vegetation N:P ratio: a new tool to detect the nature of nutrient limitation. J. Appl. Ecol. 33, 1441-1450

Liczner, Y., Schoenmaeckers, M., van Ballaer, B., Backx, H, van Pelt, D. and van Diggelen, R. 2011. Onderzoek van het ecologisch potentieel van graslanden in de regio Antwerpse Kempen. Report University of Antwerp (in Dutch)

Litchman, E. 2010. Invisible invaders: non-pathogenic invasive microbes in aquatic and terrestrial ecosystems. Ecol. Lett. 13, 1560-1572

Liu, W., Jiang, L., Hu, S., Li,L., Liu, L. and Wan, S. 2014. Decoupling of soil microbes and plants with increasing anthropogenic nitrogen inputs in a temperate steppe. Soil Biol. Biochem. 72, 116-122

Londo, G., 1976. The decimal scale for relevés of permanent quadrats. Vegetatio 33, 61-64

Lozano, Y.M., Hortal, S., Arman, C. and Pugnaire, F.I. 2014. Interactions among soil, plants, and microorganisms drive secondary succession in a dry environment. Soil Biol. Biochem. 78, 298-306

Maskell, L.C., Smart, S.M., Bullock, J.M., Thompson, K. and Stevens, C. 2010. Nitrogen deposition causes widespread loss of species richness in British habitats. Glob. Chang. Biol. 16, 671-679 
Myers, J.A. and Harms, K.E. 2009. Seed arrival, ecological filters, and plant species richness: a metaanalysis. Ecol. Lett. 12, 1250-1260

Murphy, J. and Riley, J.P. 1962. A modified single solution method for the determination of phosphate in natural waters. Anal. Chim. Acta 27, 31-36

Nemergut, D.R., Schmidt, S.K., Fukami, T., O’Neill, S.P., Bilinski, T.M., Stanish, L.F., Knelman, J.E., Darcy, J.L., Lynch, R.C., Wickey, P. and Ferrenberg, S. 2013. Patterns and processes of microbial community assembly. Microbiol Mol Biol Rev 77, 342-356

Pinheiro J, Bates D, DebRoy S, Sarkar D and R Core Team (2015)._nlme: Linear and Nonlinear Mixed Effects Models_. R package version 3.1-122, URL: http://CRAN.R-project.org/package=nlme

R Core Team, 2016. R: A Language and Environment for Statistical Computing. R Foundation for Statistical Computing, Vienna, Austria (2016) http://www.R-project.org

Read, D.J., Leake, J.R. and Perez-Morena, J. 2004. Mycorrhizal fungi as drivers of ecosystem processes in heathland and boreal forest biomes. Can. J. Bot. 82, 1243-1263

Schmidt, S.K., Nemergut, D.R., Darcy, J.L. and Lynch R. 2014. Do bacterial and fungal communities assembly differently during primary succession? Mol. Ecol. 23, 254-258

Ter Braak, C. and Šmilauer, P. 2002. CANOCO reference manual and CanoDraw for Windows user's guide: software for canonical community ordination (version 4.5). Section on Permutation Methods, Microcomputer Power, Ithaca, New York.

Török, P., Vida, E., Deák, B., Lengyel, S. and Tóthmérész, B. 2011. Grassland restoration on former croplands in Europe: an assessment of applicability of techniques and costs. Biodivers. Conserv. 20, 2311-2332

Treseder, K.K. 2008. Nitrogen additions and microbial biomass: a meta-analysis of ecosystem studies. Ecol. Lett. 11, 1111-1120

Van Diggelen, R. and Marrs, R.H. 2003. Restoring plant communities - introduction. Appl. Veg. Sci. 6, 106-110

Van der Putten, W.H., Bardgett, R.D., Bever, J.D., Bezemer, T.M., Casper, B.B., Fukami, T., Kardol, P., Klironomos, J.N., Kulmatiski, A., Schweitzer, J.A., Suding, K.N., Van de Voorde, T.F.J. and Wardle, D.A. 2013. Plant-soil feedbacks: the past, the present and future challenges. J. Ecol. 101: 265-276

Vance, E.D. and Jenkinson D.S. 1987. An extraction method for measuring soil microbial biomass C. Soil Biol. Biochem. 19:703-707

Verhagen, R., Klooker, J., Bakker, J.P. and Van Diggelen, R. 2001. Restoration success of lowproductive plant communities on former agricultural soils after top-soil removal. Appl. Veg. Sci. 4, 7582

Wardle, D.A., Bardgett, R.D., Klironomos, J.N., Setälä, H., Van der Putten, W.H. and Wall, D.H. 2004. Ecological linkages between aboveground and belowground biota. Science 304, 1629-1633 
517 Wei, C., Yu, Q., Bai, E., Lü, X., Li, Q., Xia, J., Kardol, P., Liang, W., Wang, Z. and Han, X. 2013. Nitrogen

518 deposition weakens plant-microbe interactions in grassland ecosystems. Glob. Chang. Biol. 19, 3688-

5193697

520

521 Wubs, E.R., van der Putten, W.H., Bosch, M. and Bezemer, T.M. 2016. Soil inoculation steers

522 restoration of terrestrial ecosystems. Nature Plants, 2, 1-5 


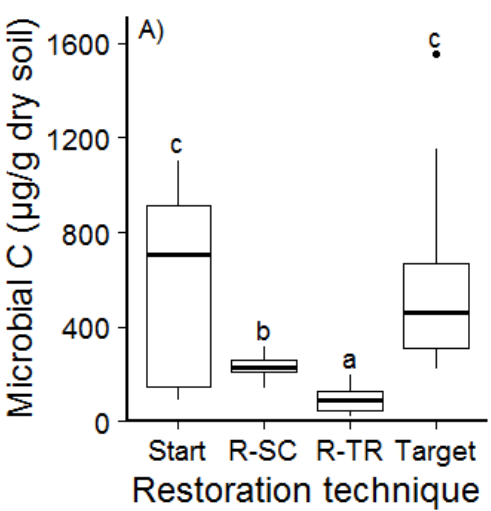
study sites were included in the analysis.
Table 1. Description of the study sites with area, location, restoration technique, years since restoration, previous land-use and degree of isolation.

\begin{tabular}{|c|c|c|c|c|c|c|c|}
\hline Category & $\begin{array}{l}\text { Restoration } \\
\text { technique }\end{array}$ & Area & $\begin{array}{l}\text { Restoration } \\
\text { period (years) }\end{array}$ & $\begin{array}{l}\text { Previous } \\
\text { land-use }\end{array}$ & Isolation & Latitude & Longitude \\
\hline Start & Agricultural & Delleburen & - & - & Not & $52.957060^{\circ}$ & $6.154318^{\circ}$ \\
\hline Start & Agricultural & Dwingeloo & - & - & Not & $52.808550^{\circ}$ & $6.422350^{\circ}$ \\
\hline Start & Agricultural & Dwingeloo & - & - & Not & $52.799900^{\circ}$ & $6.413317^{\circ}$ \\
\hline Start & Agricultural & Eexterveld & - & - & Not & $53.014232^{\circ}$ & $6.708168^{\circ}$ \\
\hline R-SC & Sod-cut & Delleburen & 10 & Meadow (F-M) & Not & $52.957987^{\circ}$ & $6.149869^{\circ}$ \\
\hline $\mathrm{R}-\mathrm{SC}$ & Sod-cut & Eemboerveld & 12 & Arable (F-A) & Highly & $53.017892^{\circ}$ & $7.093543^{\circ}$ \\
\hline $\mathrm{R}-\mathrm{SC}$ & Sod-cut & Eexterveld & 9 & Meadow (F-M) & Low & $53.015188^{\circ}$ & $6.702981^{\circ}$ \\
\hline$R-T R$ & Topsoil removal & Bakkeveen & 13 & Meadow (F-M) & Low & $53.081547^{\circ}$ & $6.280386^{\circ}$ \\
\hline$R-T R$ & Topsoil removal & Delleburen & 10 & Meadow (F-M) & Not & $52.958867^{\circ}$ & $6.152861^{\circ}$ \\
\hline$R-T R$ & Topsoil removal & Eexterveld & 9 & Meadow (F-M) & Low & $53.013391^{\circ}$ & $6.702926^{\circ}$ \\
\hline$R-T R$ & Topsoil removal & Ennemaborg & 12 & Arable (F-A) & Highly & $53.182255^{\circ}$ & $7.004271^{\circ}$ \\
\hline$R-T R$ & Topsoil removal & Tichelberg & 23 & Arable (F-A) & Highly & $53.022717^{\circ}$ & $7.005042^{\circ}$ \\
\hline Target & Heathland & Appelbergen & - & - & Highly & $53.137292^{\circ}$ & $6.640562^{\circ}$ \\
\hline Target & Heathland & Delleburen & - & - & Not & $52.958914^{\circ}$ & $6.145421^{\circ}$ \\
\hline Target & Heathland & Delleburen & - & - & Not & $52.962556^{\circ}$ & $6.138043^{\circ}$ \\
\hline Target & Heathland & Dwingeloo & - & - & Not & $52.806733^{\circ}$ & $6.405417^{\circ}$ \\
\hline Target & Heathland & Dwingeloo & - & - & Not & $52.789417^{\circ}$ & $6.422683^{\circ}$ \\
\hline Target & Heathland & Eexterveld & - & - & Highly & $53.008915^{\circ}$ & $6.701301^{\circ}$ \\
\hline
\end{tabular}

Table 2. Soil chemistry of the study sites compared to values of meta-analyses for heathlands (De Graaf et al. 2009, Liczner et al. 2011). Outcomes of a Tukey test are given between brackets, only the

\begin{tabular}{llllll}
\hline & Start (Agricultural) & R-SC (Sod-cut) & $\begin{array}{l}\text { R-TR (Topsoil } \\
\text { removal) }\end{array}$ & $\begin{array}{l}\text { Target } \\
\text { (Heathlands) }\end{array}$ & $\begin{array}{l}\text { Values meta- } \\
\text { analysis } \\
\text { heathlands }\end{array}$ \\
\hline $\mathbf{N}_{\text {total }}$ (g/100g soil) & $1.42 \pm 0.24(\mathrm{a})$ & $0.24 \pm 0.12(\mathrm{~b})$ & $0.03 \pm 0.01(\mathrm{c})$ & $0.38 \pm 0.19(\mathrm{bc})$ & $0.02(0.00-0.09)$ \\
$\mathbf{P}_{\text {total }}(\mathbf{m g} / \mathbf{1 0 0 g}$ soil) & $22.09 \pm 3.76(\mathrm{a})$ & $25.68 \pm 10.32(\mathrm{a})$ & $8.48 \pm 3.95(\mathrm{a})$ & $24.84 \pm 3.84(\mathrm{a})$ & $0.12(0-0.90)$ \\
$\mathbf{p H}(\mathrm{KCl})$ & $4.73 \pm 0.32(\mathrm{a})$ & $5.20 \pm 0.75(\mathrm{ab})$ & $4.60 \pm 0.19(\mathrm{ab})$ & $3.50 \pm 0.32(\mathrm{~b})$ & $4.3(4.0-5.4)$ \\
\hline
\end{tabular}

Figure 1. The effects of restoration technique (A), land-use (B) and isolation (C) on microbial biomass. Start: agricultural, R-SC: sod-cut, R-TR: topsoil removal, Target: heathlands, F-A: former arable and F$\mathrm{M}$ : former meadow. Boxplots show median, $1^{\text {st }}$ and $3^{\text {rd }}$ quartiles and $1.5^{*}$ IQR whiskers, the letters indicate Tukey outcomes.
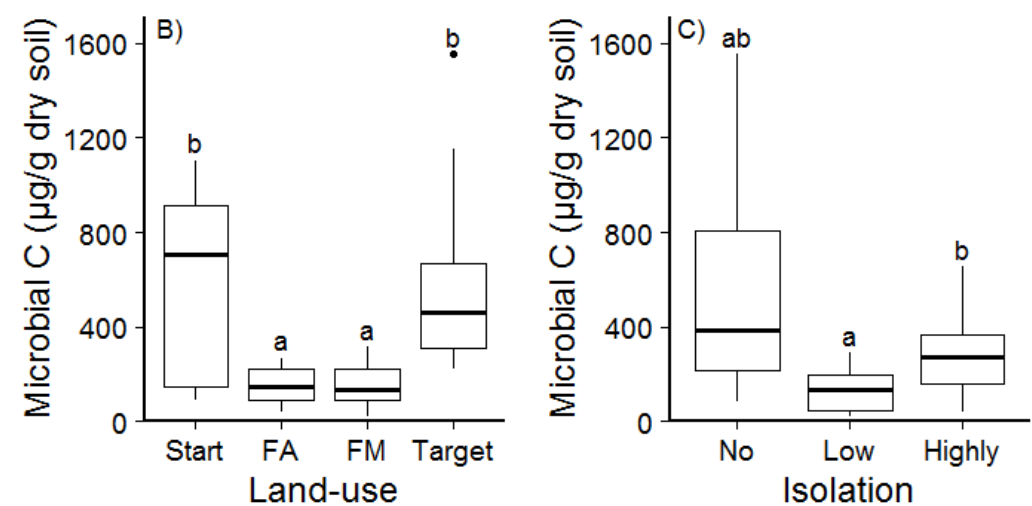


\section{A) Restoration techniques}
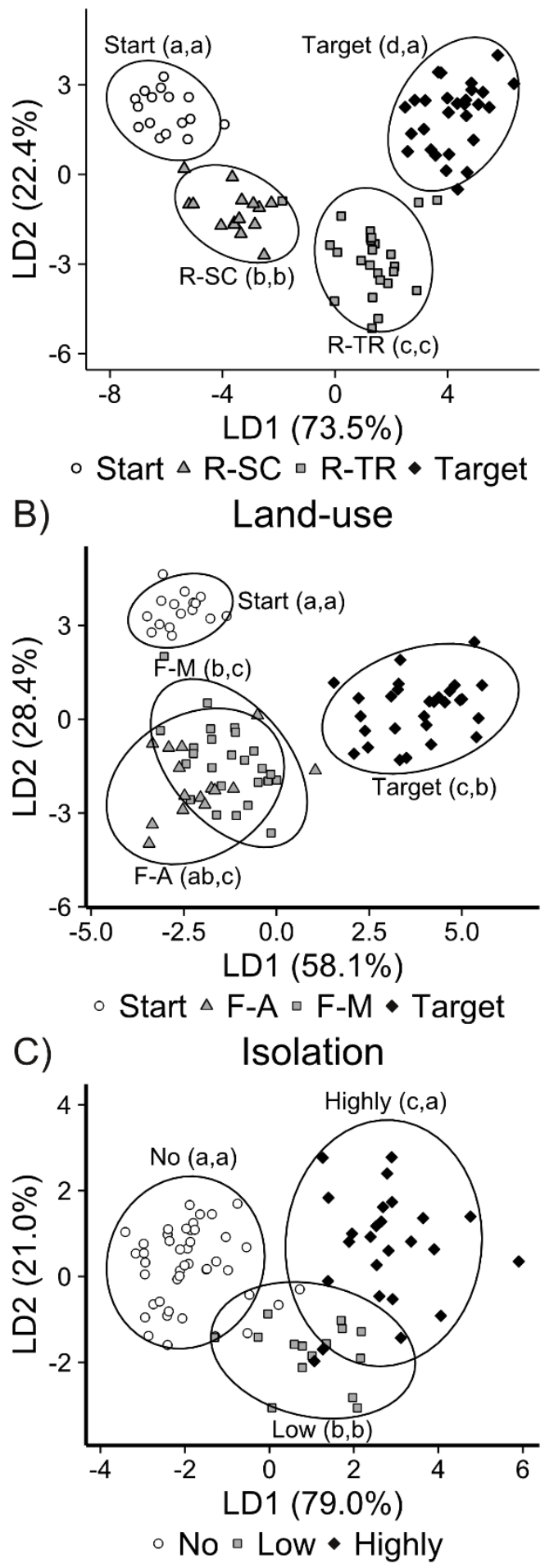

Figure 2. The first two linear discriminants of microbial community composition based on all PLFA's for restoration technique (A), land-use (B) and isolation (C). Percentages view the amount of variation explained by each axis. Tukey outcomes for LD1 and LD2 are given after each group between brackets. Ellipses represent 95\% confidence intervals. Start: agricultural, R-SC: sod-cut, RTR: topsoil removal, Target: heathlands, F-A: former arable and F-M: former meadow. 

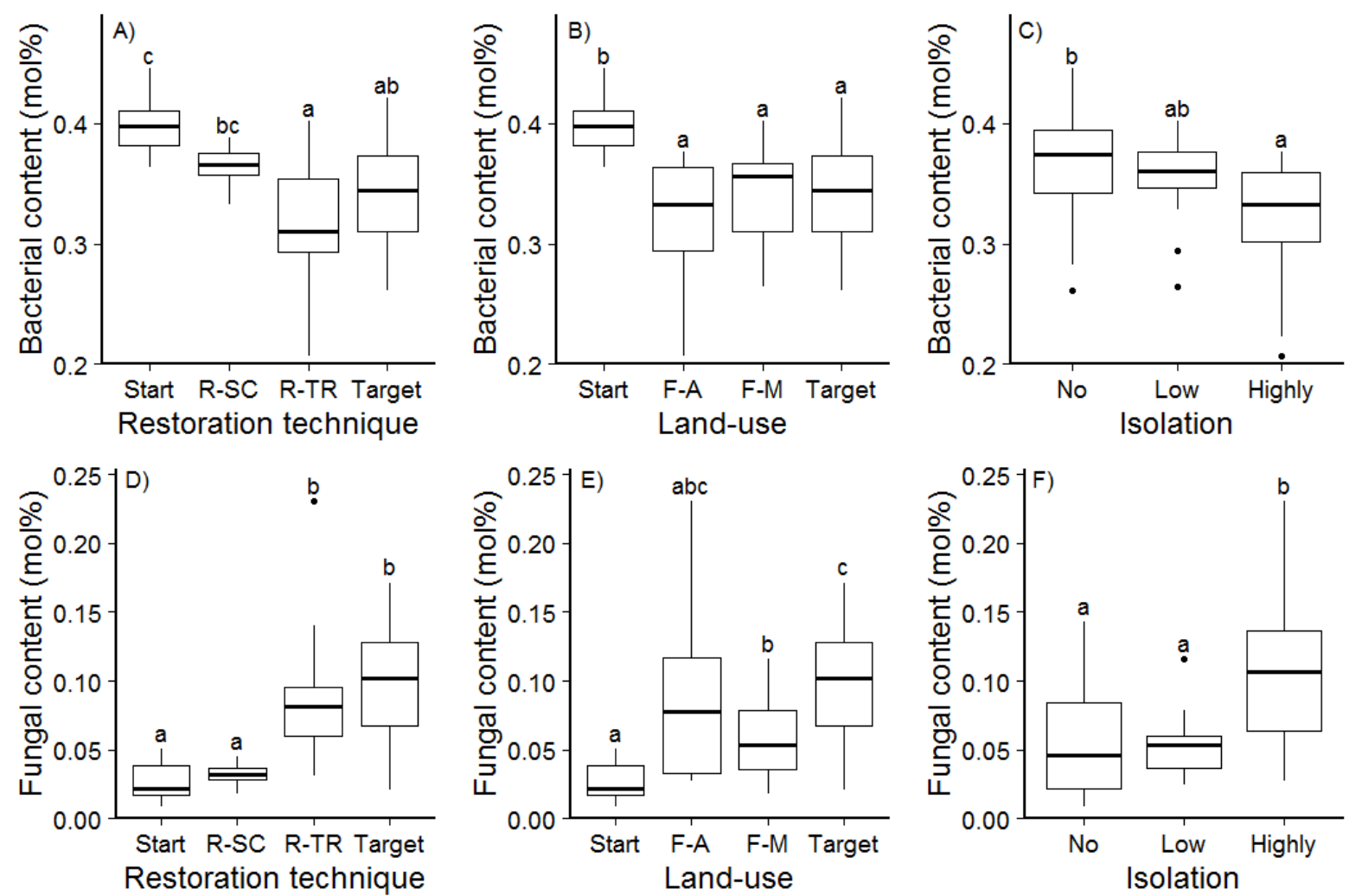
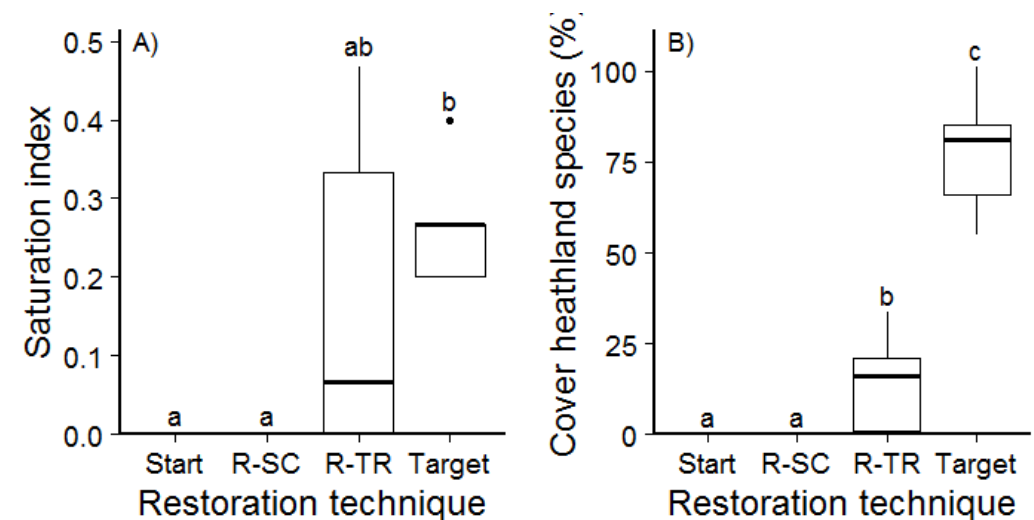

562 Figure 4. The effect of restoration technique on Saturation index (A), cover of characteristic

563 heathland species (B) and cover of agricultural species (C). Start: agricultural, R-SC: sod-cut, R-TR:

564 topsoil removal and Target: heathlands. Boxplots show median, $1^{\text {st }}$ and $3^{\text {rd }}$ quartiles and $1.5^{*} I Q R$

565 whiskers, the letters indicate Tukey outcomes. 


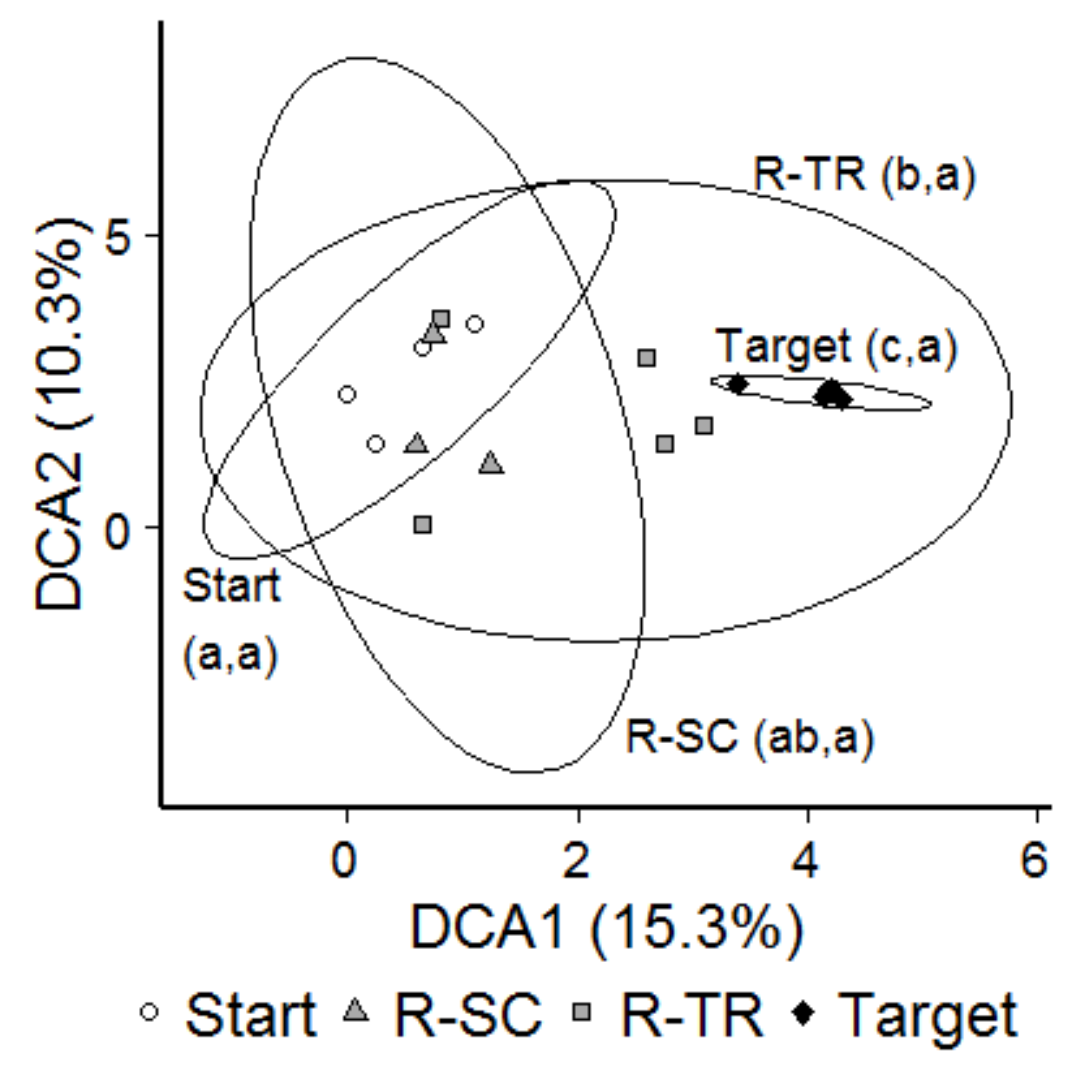

570 Figure 5. A Detrended Component Analyis (DCA) of the effects of restoration technique on vegetation 571 composition. Percentages view the amount of variation explained by each axis. Tukey outcomes for 572 DCA1 and DCA2 are given after each group between brackets. Ellipses represent $95 \%$ confidence 573 intervals. Start: agricultural, R-SC: sod-cut, R-TR: topsoil removal and Target: heathlands. (note Figure 5: TIFF-format only preview, .EPS and .PDF source files included. One-column graph) 


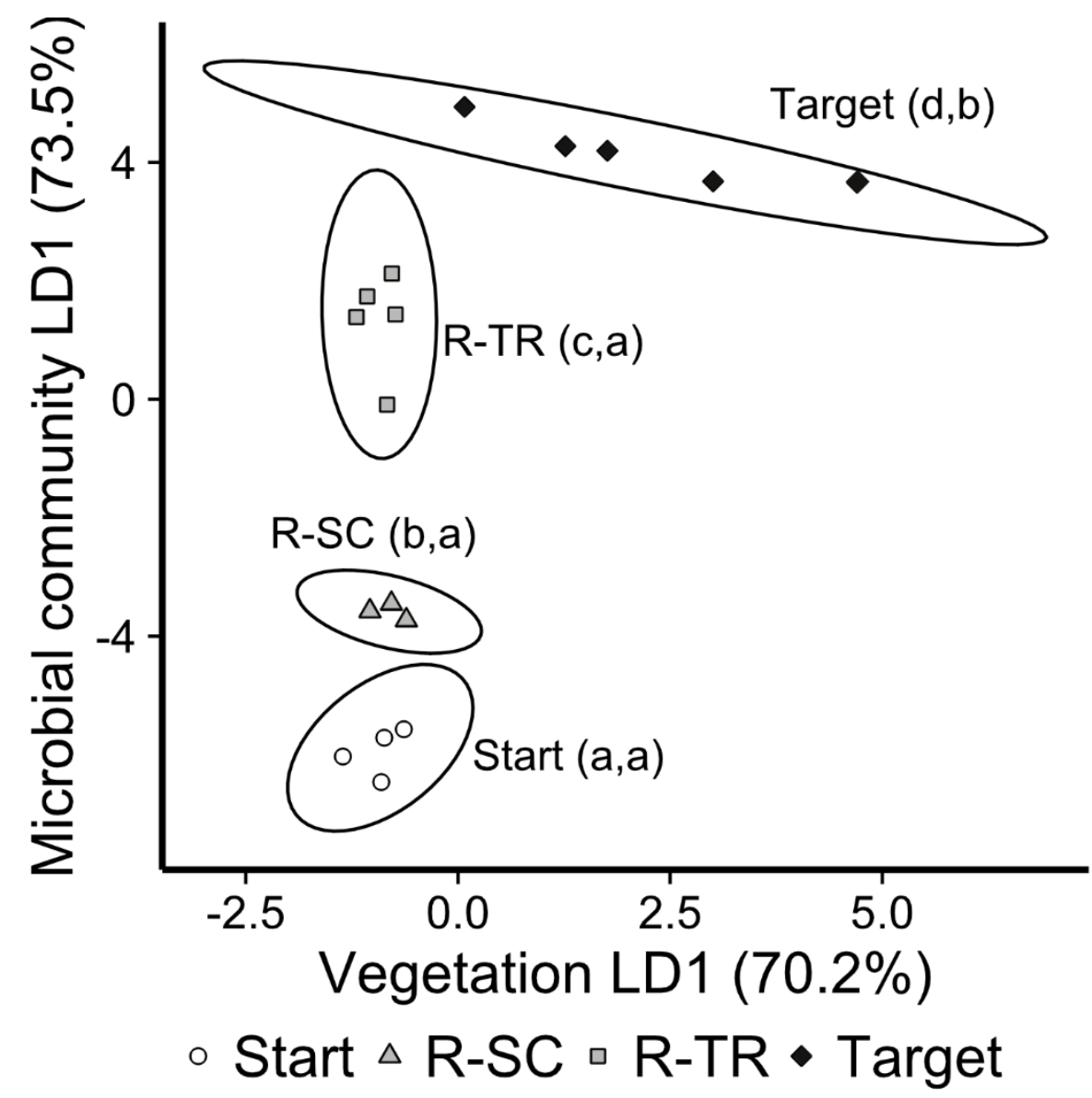

578 Figure 6. The first Linear Discriminant of vegetation composition versus the first Linear Discriminant

579 of microbial community composition for restoration techniques. Tukey outcomes for microbial

580 community and vegetation are given after each group between brackets. Ellipses represent $95 \%$ confidence intervals. Start: agricultural, R-SC: sod-cut, R-TR: topsoil removal and Target: heathlands. 
Faithfulness values obtained from SynBioSys (Hennekens et al. 2010) of characteristic heathland species to the dry heath (Calluno-Ulicetea), wet heath (Erica tetralices) or Nardetea plant community observed in the vegetation relevés. Only species with a faithfulness higher than 20 were included.

\begin{tabular}{lll}
\hline Species & Plant community & Faithfulness \\
\hline Calluna vulgaris & Calluno-Ulicetea & 24.28 \\
Carex oederi & Nardetea & 21.97 \\
Carex panicea & Nardetea & 30.66 \\
Carex pilulifera & Nardetea & 23.31 \\
Dactylorhiza maculata & Nardetea & 42.86 \\
Erica tetralix & Ericetum tetralicis & 26.26 \\
Festuca ovina & Nardetea & 50.00 \\
Galium saxatile & Nardetea & 41.89 \\
Genista anglica & Nardetea & 36.22 \\
Genista tinctoria & Calluno-Ulicetea & 22.49 \\
Juncus squarrosus & Nardetea & 39.47 \\
Luzula campestris & Nardetea & 24.53 \\
Nardus stricta & Nardetea & 59.96 \\
Potentilla erecta & Nardetea & 33.73 \\
Trichophorum cespitosum & Nardetea & 29.85 \\
\hline
\end{tabular}


Statistics of all analysed parameters with application of $\ln (x+1)$ transformation, statistical test and post-hoc Tukey test. Statistical tests: ANOVA: Analysis of Variance and LME: Linear Mixed-Effect Model. Abbreviations factors: RT: restoration technique, PL: previous land-use and IS: isolation.

\begin{tabular}{|c|c|c|c|c|c|c|c|c|c|c|c|}
\hline \multirow[t]{4}{*}{ Measurement } & \multirow[t]{4}{*}{ Parameter } & \multirow{4}{*}{$\begin{array}{c}\operatorname{In}(x+1) \\
\text { trans- } \\
\text { for- } \\
\text { med }\end{array}$} & \multicolumn{4}{|c|}{ Statistical analysis } & \multicolumn{5}{|c|}{ Tukey } \\
\hline & & & \multirow[t]{3}{*}{ Test } & \multirow[t]{3}{*}{$d f$} & \multirow[t]{3}{*}{$F$} & \multirow{3}{*}{$p$} & \multirow{3}{*}{$\begin{array}{l}R T \\
P L \\
I S\end{array}$} & \multirow{3}{*}{$\begin{array}{l}\text { Start } \\
\text { Start } \\
\text { No }\end{array}$} & \multirow{3}{*}{$\begin{array}{l}R-S C \\
\text { F-A } \\
\text { Low } \\
\end{array}$} & \multirow{3}{*}{$\begin{array}{l}\text { R-TR } \\
\text { F-M } \\
\text { Highly }\end{array}$} & \multirow{3}{*}{$\begin{array}{l}\text { Target } \\
\text { Target }\end{array}$} \\
\hline & & & & & & & & & & & \\
\hline & & & & & & & & & & & \\
\hline \multirow{3}{*}{$\begin{array}{l}\text { Soil chemistry } \\
\text { (only RT) }\end{array}$} & Ntotal & yes & LME & 3,4 & 40,80 & 0,0019 & & a & $\mathrm{b}$ & c & bc \\
\hline & Ptotal & yes & LME & 3,1 & 4,99 & 0,3154 & & a & a & a & a \\
\hline & $\mathrm{pH}(\mathrm{KCl})$ & no & LME & 3,5 & 7,38 & 0,0277 & & a & $a b$ & $a b$ & $\mathrm{~b}$ \\
\hline \multirow{3}{*}{$\begin{array}{l}\text { Microbial } \\
\text { biomass }\end{array}$} & Restoration technique & yes & LME & 3,67 & 41,81 & $<0,0001$ & & c & $\mathrm{b}$ & a & c \\
\hline & Previous land-use & yes & LME & 3,67 & 19,20 & $<0,0001$ & & $b$ & a & a & $b$ \\
\hline & Isolation & yes & LME & 2,68 & 8,32 & 0,0006 & & $a b$ & a & $b$ & \\
\hline \multirow{3}{*}{$\begin{array}{l}\text { PLFA-Total } \\
\text { bacteria }\end{array}$} & Restoration technique & yes & LME & 3,73 & 16,38 & $<0,0001$ & & c & bc & a & $a b$ \\
\hline & Previous land-use & yes & LME & 3,73 & 10,11 & $<0,0001$ & & $b$ & a & a & a \\
\hline & Isolation & yes & LME & 2,74 & 5,19 & 0,0078 & & $\mathrm{~b}$ & $a b$ & a & \\
\hline \multirow[t]{3}{*}{ PLFA-Fungi } & Restoration technique & yes & LME & 3,73 & 28,35 & $<0,0001$ & & a & $\mathrm{a}$ & b & $b$ \\
\hline & Previous land-use & yes & LME & 3,73 & 17,28 & $<0,0001$ & & a & $a b c$ & $b$ & c \\
\hline & Isolation & yes & LME & 2,74 & 9,99 & 0,0001 & & a & a & $b$ & \\
\hline \multirow[t]{3}{*}{ PLFA-PCA } & Restoration technique & no & LME & 3,73 & 62,32 & $<0,0001$ & & & & & \\
\hline & Previous land-use & no & LME & 3,73 & 49,56 & $<0,0001$ & & & & & \\
\hline & Isolation & no & LME & 2,74 & 12,17 & $<0,0001$ & & & & & \\
\hline \multirow[t]{6}{*}{ PLFA-LDA } & RT LD1 & no & ANOVA & 3 & 435,51 & $<0,0001$ & & a & $\mathrm{b}$ & c & $d$ \\
\hline & RT LD2 & no & ANOVA & 3 & 132,68 & $<0,0001$ & & a & $\mathrm{b}$ & c & a \\
\hline & PL LD1 & no & ANOVA & 3 & 208,34 & $<0,0001$ & & a & $a b$ & $b$ & c \\
\hline & PL LD2 & no & ANOVA & 3 & 101,73 & $<0,0001$ & & a & c & c & $\mathrm{b}$ \\
\hline & IS LD1 & no & ANOVA & 2 & 180,84 & $<0,0001$ & & a & $b$ & c & \\
\hline & IS LD2 & no & ANOVA & 2 & 30,67 & $<0,0001$ & & a & $\mathrm{b}$ & a & \\
\hline \multirow[t]{3}{*}{$\begin{array}{l}\text { Vegetation } \\
\text { (only RT) }\end{array}$} & $\begin{array}{l}\text { Saturation index } \\
\text { Cover heathland }\end{array}$ & yes & LME & 3,7 & 5,19 & 0,0337 & & a & $a$ & $a b$ & b \\
\hline & species & yes & LME & 3,7 & 37,83 & 0,0001 & & $a$ & a & $b$ & c \\
\hline & $\begin{array}{l}\text { Cover agricultural } \\
\text { species }\end{array}$ & yes & LME & 3,7 & 7,03 & 0,0161 & & c & bc & $a b$ & a \\
\hline \multirow{2}{*}{$\begin{array}{l}\text { Vegetation- } \\
\text { DCA RT }\end{array}$} & RT DCA1 & no & LME & 3,7 & 21,37 & 0,0007 & & a & $a b$ & $\mathrm{~b}$ & c \\
\hline & RT DCA2 & no & LME & 3,7 & 0,57 & 0,6537 & & a & a & a & a \\
\hline \multirow{2}{*}{$\begin{array}{l}\text { Vegetation- } \\
\text { LDA RT }\end{array}$} & RT LD1 & no & ANOVA & 3 & 11,06 & 0,0007 & & $a$ & a & a & b \\
\hline & RT LD2 & no & ANOVA & 3 & 3,97 & 0,0327 & & $a$ & $a b$ & $b$ & $a b$ \\
\hline
\end{tabular}

